\title{
Patterns of Ichthyobodo necator sensu stricto infections on hatchery-reared Atlantic salmon Salmo salar in Norway
}

\author{
T. E. Isaksen ${ }^{1, *}$, E. Karlsbakk ${ }^{2}$, G. A. Sundnes ${ }^{1,3}$, A. Nylund ${ }^{1}$ \\ ${ }^{1}$ Department of Biology, University of Bergen, Thormøhlensgaten 55, 5020 Bergen, Norway \\ ${ }^{2}$ Institute of Marine Research, Nordnesgaten 50, 5817 Bergen, Norway \\ ${ }^{3}$ Aqua-Lab AS, Eidsvågveien 150, 5105 Eidsvåg, Norway
}

\begin{abstract}
Infection patterns with ectoparasitic flagellates belonging to the genus Ichthyobodo were studied in an Atlantic salmon Salmo salar (L.) hatchery in western Norway during an 11 mo period, from eyed eggs to smoltification. Since the earlier species designation Ichthyobodo necator (sensu lato, s.l.) has been shown to represent a complex of several species, the epizootiology of different Ichthyobodo spp. is poorly known. Therefore, we employed molecular methods to ascertain the specific identity of the parasites detected in our study. Only $I$. necator in the recently redefined and restricted sense occurred ( $I$. necator sensu stricto, s.s.). We observed a 2-peak pattern of infection; the first peak occurred among fry in March and the second peak among fingerlings and pre-smolt in August and September. Skin lesions observed on fingerlings and pre-smolt were significantly associated with Ichthyobodo infections. Also, these infections were negatively correlated with both haematocrit values (Hct) and the condition factor $(\mathrm{K})$ of the fish. The patterns of infection on the farmed salmon suggest that $I$. necator s.s. is an opportunistic parasite of salmon, flourishing in periods when susceptible hosts are present and the environment favours parasite proliferation. Our study is the first to detect and identify I. necator s.s. on wild-caught adult salmonids (brown trout $S$. trutta L.). Wild salmonids and sticklebacks Gasterosteus aculeatus (L.) caught in the lakes serving as a water supply to the hatchery were found infected with I. necator s.s., hence these are the likely sources of parasites entering the hatchery via the inlet water.
\end{abstract}

KEY WORDS: Ichthyobodo necator · Salmon · Ichthyobodonidae · Fresh water · Epizootiology · SSU rDNA · Parasite · Ichthyobodosis

Resale or republication not permitted without written consent of the publishe

\section{INTRODUCTION}

Flagellates identified as Ichthyobodo necator (Henneguy 1883) have been associated with disease and mortalities of juvenile salmonids worldwide (Robertson 1985). Several studies of Ichthyobodo infection dynamics in freshwater-reared salmonids have been conducted in Europe (e.g. Robertson 1979, Wootten \& Smith 1980, Buchmann \& Bresciani 1997, RintamakiKinnunen \& Valtonen 1997). However, recent molecular studies have shown that the old concept of $I$. necator (I. necator sensu lato, s.l.) comprises several Ichthyobodo spp. that may be discerned by their small subunit ribosomal DNA (SSU rDNA) sequences (Todal et al. 2004, Callahan et al. 2005, Isaksen et al. 2007). In a previous study, we delimited I. necator (sensu stricto, s.s.) as a parasite thus far only known to infect freshwater fishes in Europe (Isaksen et al. 2007). However, several Ichthyobodo spp. may infect salmonids worldwide (Todal et al. 2004, Callahan et al. 2005), hence our understanding of the epizootiology of the different Ichthyobodo spp. identified by molecular means is scant, and the interpretation of studies dealing with the infection dynamics of $I$. necator s.l. is difficult. In Norway, salmonid hatcheries experience a recurring pattern with Ichthyobodo infections during smolt production, often with heavy infections that require treatment. Wild fish in lakes and rivers may act as reser- 
voirs of parasites, infecting hatchery-reared salmonids via the inlet water. Parasite interactions between wild and farmed salmonids have been studied (Wootten \& Smith 1980, Valtonen \& Koskivaara 1994), but there are no descriptions or detection of Ichthyobodo spp. from wild fish in these studies.

The purpose of the present study was to examine the acquisition and progress of Ichthyobodo spp. infections on hatchery-reared juvenile salmon through a production cycle in Norway, identify the Ichthyobodo species involved and disclose natural hosts in the water source.

\section{MATERIALS AND METHODS}

Juvenile Atlantic salmon Salmo salar from a single cohort were sampled from a hatchery in western Norway $\left(60^{\circ} 11^{\prime} 24^{\prime \prime} \mathrm{N}, 5^{\circ} 45^{\prime} 50^{\prime \prime} \mathrm{E}\right)$. The hatchery receives water from a lake connected to a larger lake through a short channel. Anadromous salmonids are prevented from entering these lakes by a dam. Brown trout Salmo trutta (L.), Arctic charr Salvelinus alpinus (L.), threespined stickleback Gasterosteus aculeatus (L.), and eel Anguilla anguilla (L.) are native to the lakes, but Atlantic salmon and rainbow trout Oncorhynchus mykiss Walbaum escaped from net pens situated in the lakes are also common. Glass eels migrate from sea to the lakes by moving across land.
We initially studied a single tank (Tank A) that was subject to the regular rearing routine of the hatchery. Tank A was routinely sorted by size in mid-June, and sampling continued on both subsequent groups (small/large, Table 1). The hatchery administered prophylactic or therapeutic treatments for protozoans using a $35 \%$ solution of formaldehyde (= $100 \%$ formalin) in a ratio of 1:4000 that was directly added to the water in the fish tanks. The formaldehyde concentration was diluted over time by the water flow with a half-life of approximately $25 \mathrm{~min}$ in the tank. The fish tanks in our study were treated on 10 March, 21 July and 1 August (see Fig. 1, 'F'). Prior to a prophylactic formalin treatment motivated by the detection of Ichthyobodo infections, an 'Untreated tank' (U) was established with fish from Tank A in March. Tank U did not receive formalin treatments, and fish were not subject to handling (e.g. grading, thinning).

Tank U terminated due to an accident 30 June and was re-established with representative numbers of small / large fish originating from Tank A. An outbreak of a bacterial disease (furunculosis) in a part of the hatchery required destruction of all fish on 18 August, ending the sampling from tank-reared fish. Furunculosis did not appear in the studied tanks. Sampling continued on fish from the same cohort that had been transferred to net pens in the largest lake upstream from the hatchery $6 \mathrm{wk}$ earlier. The pen-reared fish

Table 1. Salmo salar. Farmed Atlantic salmon examined for Ichthyobodo necator infections. The tank-reared fish (except the untreated group) were sorted by size in mid-June (small / large). Data for the untreated group are shown in parentheses. Water temperatures are given as the mean of the $7 \mathrm{~d}$ preceding the sampling date. Fish densities were estimated monthly

\begin{tabular}{|c|c|c|c|c|c|}
\hline Date & Host & $\begin{array}{l}\text { Sample } \\
\text { size (N) }\end{array}$ & $\begin{array}{c}\text { Fish total } \\
\text { length }(\mathrm{mm})\end{array}$ & $\begin{array}{c}\text { Water } \\
\text { temperature }\left({ }^{\circ} \mathrm{C}\right)\end{array}$ & $\begin{array}{l}\text { Fish density } \\
\left(\mathrm{g} \mathrm{l}^{-1} \text { water }\right)\end{array}$ \\
\hline $10 \mathrm{Jan}$ & Eyed eggs & 43 & - & 6.6 & \\
\hline 29 Jan & Alevins & 100 & 25 & 7.9 & \\
\hline $11 \mathrm{Feb}$ & Alevins & 100 & 27 & 9.1 & 2 \\
\hline $26 \mathrm{Feb}$ & Fry & 100 & 29 & 11.3 & \\
\hline 9 Mar & Fry & 60 & 34 & 14.7 & \\
\hline 24 Mar & Fry & $100(100)$ & $43(43)$ & 15.8 & $5(2)$ \\
\hline $7 \mathrm{Apr}$ & Fry & $100(100)$ & $51(56)$ & 15.7 & \\
\hline 26 Apr & Fingerlings & $100(100)$ & $67(70)$ & 15.4 & $10(8)$ \\
\hline 12 May & Fingerlings & $112(100)$ & $79(78)$ & 16.3 & \\
\hline 29 May & Fingerlings & $101(61)$ & $88(100)$ & 14.7 & $32(7)$ \\
\hline 14 Jun & Fingerlings & 36 / 64 (60) & 90 / 121 (120) & 14.3 & \\
\hline 30 Jun & Fingerlings & 36 / 64 (34) & 94 / 138 (154) & 17.5 & 32 / 57 (22) \\
\hline $17 \mathrm{Jul}$ & Fingerlings & 30 / 31 (30) & $125 / 155(128)^{a}$ & 17.1 & \\
\hline $30 \mathrm{Jul}$ & Fingerlings & 36 / 30 (39) & 127 / 165 (142) & 17.7 & $32 / 57$ (38) \\
\hline $18 \mathrm{Aug}$ & Fingerlings & 56 / 17 (39) & 136 / 170 (165) & 16.1 & 37 / 59 (53) \\
\hline $7 \mathrm{Sep}$ & Pre-smolt & 46 & 170 & 15.4 & \\
\hline $28 \mathrm{Sep}$ & Pre-smolt & 41 & 198 & 12.6 & 9 \\
\hline $3 \mathrm{Nov}$ & Pre-smolt & 40 & 229 & 7.9 & 10 \\
\hline \multicolumn{2}{|c|}{ Number of fish examined } & $1443(662)$ & & & \\
\hline
\end{tabular}


were vaccinated (multivalent vaccine with oil-based adjuvant against bacterial diseases, see ' $V$ ' in Fig. 1) by intraperitonal injection in late October, using tricaine methanesulphonate (MS-222) as an anaesthetic.

The farmed salmon were sampled approximately biweekly through production during the year 2000 ( $N=2105$, Table 1). In addition, a total of 131 wild fish collected from the lakes by angling, gillnetting or trapping were examined for Ichthyobodo spp. infections (see Table 5).

Examination of the fish. In the laboratory, the fish were individually euthanised with $3 \%$ benzocaine (stock solution: $10 \% \mathrm{wt} \mathrm{vol}^{-1}$ in $96 \%$ ethanol) before examination. This concentration of benzocaine did not detectably affect the motility of the Ichthyobodo specimens. Fish weight $(\mathrm{W}, \mathrm{g})$ and total length $(\mathrm{L}, \mathrm{mm})$ were measured. From the hatchery-reared salmon (beginning on 12 May), blood was collected into heparinised microhaematocrit tubes from the caudal blood vessels to determine haematocrit (Hct) using a microhaematocrit centrifuge (Sigma 201m; $13700 \times$ g, 5 min). Skin scrapings were taken with a cover slip $(18 \times 18 \mathrm{~mm})$, from the left side of the fish. Scrapings from alevins and small fingerlings $(<10 \mathrm{~g})$ were taken from the pectoral to the caudal fin, while samples from larger fish ( $>10 \mathrm{~g}$ ) were taken from the basis of the pectoral fin to the start of the dorsal fin. The cover slips were added to slides and examined with a light microscope at 250 to $400 \times$ magnification. Intensity of Ichthyobodo infections was ranked on a scale from 1 to 3, representing respectively $<10$ (slight infection), 10 to 50 (moderate) and $>50$ (heavy) Ichthyobodo cells in the preparation. Primary filaments from the left 2 nd gill arch were also removed and examined. Intensity of Ichthyobodo infections was ranked in the same way as for the skin. Air-dried smears and ethanol-conserved samples from fish with high Ichthyobodo sp. intensities were retained.

Wild-caught salmonids were killed by a blow to the head, and air-dried smears were prepared from the gills and skins on site. The smears were stained and examined as described by Isaksen et al. (2007). The sticklebacks were brought live to the laboratory and examined for Ichthyobodo infections in the same manner as the hatchery-reared salmon.

PCR and sequencing. DNA was extracted from ethanol-conserved gill and skin samples, or in a few cases from air-dried smears (brown trout), as described previously (Isaksen et al. 2007). PCR was performed using the primers KinSSUF1 / Br10 (annealing temperature $\left.55^{\circ} \mathrm{C}\right), \mathrm{BF} 5 / \mathrm{BR} 5\left(58^{\circ} \mathrm{C}\right), \mathrm{BF} 6 / \mathrm{BR} 3\left(55^{\circ} \mathrm{C}\right)$ or BF6 / BR11 (55 $\left.{ }^{\circ} \mathrm{C}\right)$ (Callahan et al. 2002, Todal et al. 2004, Table 2), amplifying SSU rDNA of Ichthyobodo spp. The PCR products were purified using the E.Z.N.A. ${ }^{\text {TM }}$ Cycle Pure Kit (Omega Bio-Tek) and then sequenced using the BigDye ${ }^{\circledR}$ Terminator v3.1 Cycle Sequencing kit (Applied Biosystems) with the amplification primers listed above. The sequence data were assembled with the help of NTI Vector software (InforMax), and GenBank searches were done with BLAST (2.0). The Vector NTI Suite software package was used for multiple alignments of the sequences.

Two different Ichthyobodo species are known to infect salmonids in freshwater in Europe; I. necator s.s. (see Isaksen et al. 2007) and Ichthyobodo sp. II sensu Todal et al. (2004). To identify the species and exclude the possibility of multiple infections, specific primers were constructed (CoNec and CoEur primers, respectively, Table 2) on the basis of an alignment of all available Ichthyobodo spp. sequences in GenBank. Samples of Ichthyobodo sp. II (e.g. Ichthyobodo-infected freshwater-reared Atlantic salmon from western Norway, $60^{\circ} 30^{\prime} 01^{\prime \prime} \mathrm{N}, 07^{\circ} 09^{\prime} 11^{\prime \prime} \mathrm{E}$ ) were used as positive controls for the CoEur primers. Gradient PCR was used to determine optimum annealing temperatures for the specific primer sets. Optimal temperatures for the $\mathrm{CoNec}$ and $\mathrm{CoEur}$ assays are $60^{\circ} \mathrm{C}$ and $56^{\circ} \mathrm{C}$, respectively.

Statistics. Statistical analyses were performed in Microsoft ${ }^{\circledR}$ Excel 2003 and Statistica ${ }^{\circledR}$ (8.0). Fulton's condition factor $(\mathrm{K})$ was calculated from the relationship between weight $(W, \mathrm{~g})$ and length $(L, \mathrm{~cm})$ using the formula: $\mathrm{K}=100 W L^{-3}$. Correlations between 2 variables were examined using the Spearman rankorder correlation coefficient $\left(\mathrm{r}_{\mathrm{s}}\right)$. The Kendall partial rank-order correlation coefficient $T_{x y \cdot z}$ (Siegel \& Castellan 1988) was used to account for the effect of a third variable in correlation analyses between 2 variables. Associations were examined using a chisquared test $\left(\chi^{2}\right)$. Probabilities (p) of 0.05 or less were considered significant.

\section{RESULTS}

\section{Pattern of Ichthyobodo necator infection}

In the hatchery, the first infections appeared in fry in March (Tank A), 2 wk after commencement of first feeding, when $15 \%$ and $25 \%$ showed gill and skin infections, respectively. Total prevalence was $38 \%$. No Ichthyobodo parasites could be detected after formalin treatment of this tank. However, in Tank U, established just prior to the formalin treatment, with the same fish, the Ichthyobodo infections also disappeared (Fig. 1). The flagellate was not detected again until late July when the tank with the smaller fish following sizegrading of Tank A showed a marked increase in prevalence despite 2 formalin treatments (' $\mathrm{F}$ ', Fig. 1). Infections never occurred in the tank with the large fish 


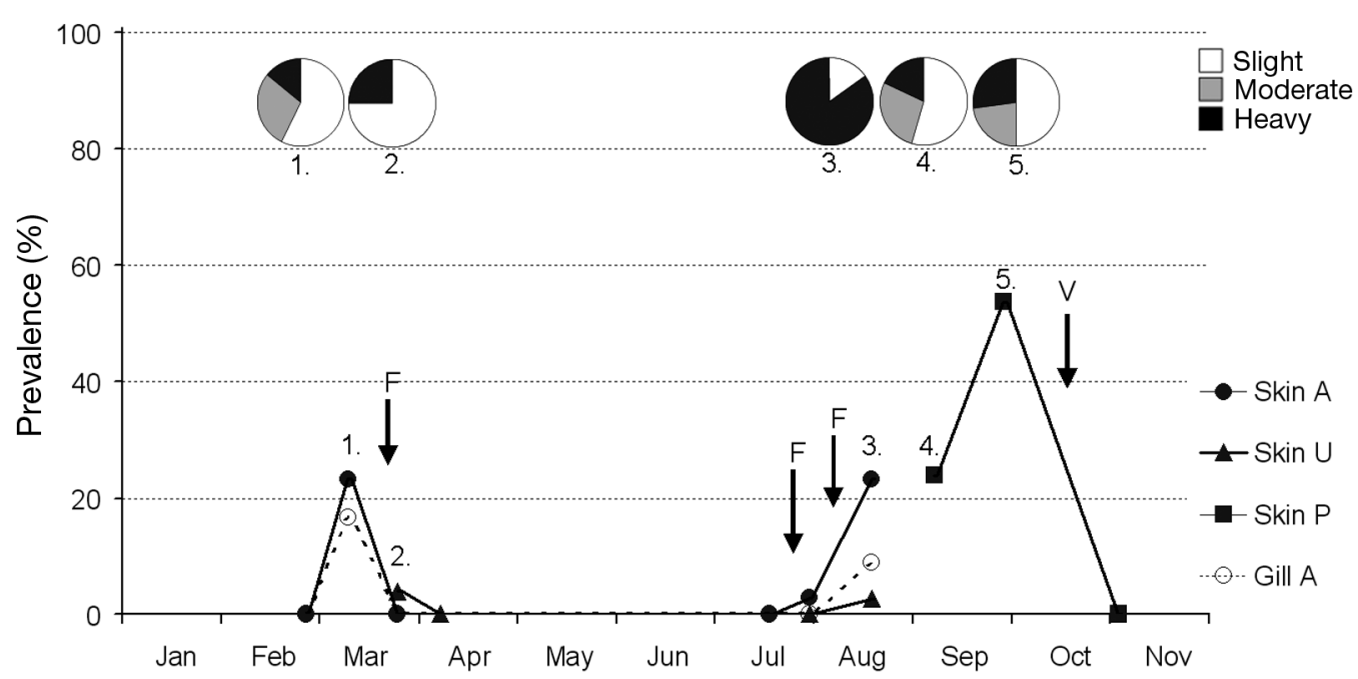

Fig. 1. Ichthyobodo necator infecting Salmo salar. Prevalence and intensities of infections in a farmed cohort of Atlantic salmon. The salmon reared in the untreated tank (U) were not exposed to handling (i.e. grading and thinning) or formalin treatment. Tank A was treated with formalin on 3 occasions (' $F$ '). The pen-reared fish (P) were vaccinated ('V') in October. Prevalence of skin and gill infections from A, U and P are shown in the line diagram. Gill infections were only detected in Tank A. Ranked intensities of Ichthyobodo infections on the skin of salmon are shown in pie charts. Intensities of infection are ranked on a scale from 1 to 3 , where 1 (white), <10 Ichthyobodo cells observed in the smear; 2 (grey), 10-50; 3 (black), >50. Heavy infections (>50 Ichthyobodo cells) were observed on five occasions (numbered 1 to 5) during the sampling period

following size-grading of Tank A. However, infections occurred among fish from the same cohort transferred to on-growing pens in the lake, where maximum prevalence $(54 \%)$ occurred on pre-smolt in late September. In these larger pen-reared fish, only skin infections occurred. No Ichthyobodo infections could be detected early in November, $2 \mathrm{wk}$ after the fish had been vaccinated (' $\mathrm{V}$ ' in Fig. 1). Ichthyobodo infections were observed on the examined salmon at a watertemperature range of 11.9 to $16.7^{\circ} \mathrm{C}$ and a $\mathrm{pH}$ range of 5.7 to 6.2 .

The heaviest infections were observed in August among the small fish following size-grading of Tank A. Prevalence and intensity of the Ichthyobodo infections are shown in Fig. 1. The relationship between Ichthyobodo intensities and size of the host was examined in the samples with high prevalence of infection

Table 2. Primers targeting 18S rRNA genes of Ichthyobodo necator sensu stricto (Isaksen et al. 2007) and Ichthyobodo sp. II (Todal et al. 2004). The BR11 primer matches both Ichthyobodo species. The CoNec-primers are specific to I. necator sensu stricto, and the CoEur-primers are specific to Ichthyobodo sp. II. Positions of the primers refer to accession no. AY028448

\begin{tabular}{|lcc|}
\hline Name & Sequence & Position \\
\hline BR11 & 5'-CAAATGGCAGGGACGTAGTC-3' & $1900-1920$ \\
CoNec F1 & 5'-AGACCTTCGGGTATGGGATCG-3' & $533-549$ \\
CoNec R1 & 5'-TCGGAATCGGAGTCCACC-3' & $1016-1037$ \\
CoEur F1 & 5'-CTCGCCTTCGGGTGAGG-3' & $533-549$ \\
CoEur R1 & 5'-GCCCGTAGCGTGTGATGAC-3' & $824-842$ \\
\hline
\end{tabular}

(Table 3). In March, the larger fry were more intensely infected on the skin than the smaller ones, while an opposite trend was evident when considering the gill infections. However, when the parasite re-emerged in August, both gill and skin infections were negatively correlated with size. The same pattern was significant in skin infections early in September, but no such correlation was found in late September.

In August, Hct values and condition factor (Fulton's K) correlated negatively with intensities of Ichthyobodo infections, independent of the length of the fish $\left(\mathrm{n}=36, \mathrm{~T}_{(\text {Hct)(Ichthyobodo) }) \text { Length }}=-0.31, \mathrm{p}<0.005 ; \mathrm{n}=56\right.$, $\left.\mathrm{T}_{(\mathrm{K})(\text { Ichthyobodo) } \text {. Length }}=-0.35, \mathrm{p}<0.001\right)$. In early September, intensity of Ichthyobodo infections correlated negatively with Hct $\left(\mathrm{n}=46, \mathrm{r}_{\mathrm{s}}=-0.38, \mathrm{p}=0.034\right)$ but not with K. However, in late September there were no correlations between Ichthyobodo intensity and Hct or K (Table 4).

In periods with peak Ichthyobodo prevalence and intensity in the hatchery, a pale coating on the body surface was observed in some fish, particularly evident dorsal near the dorsal fin and at the body sides. Fresh mucus from the skin of these fish was more opaque than normal, and often, but not always, associated with heavy Ichthyobodo infections. 'Flashing' (fish rubbing against tank or pen) occurred among Ichthyobodo-infected fish, even when the infections were slight. 
Table 3. Ichthyobodo necator infections on hatchery-reared salmon Salmo salar. Correlations between host size (length) and infection level. N: number of fish examined; $\mathrm{r}_{\mathrm{s}}$ : Spearman rank correlation coefficient

\begin{tabular}{|llllrr|}
\hline $\begin{array}{l}\text { Sampling } \\
\text { date }\end{array}$ & Host & Site & $\mathrm{N}$ & \multicolumn{1}{c|}{$\mathrm{r}_{\mathrm{s}}$} & $\mathrm{p}$ \\
\hline $9 \mathrm{Mar}$ & Fry & Skin & 59 & 0.28 & 0.03 \\
& & Gills & 59 & -0.23 & 0.08 \\
18 Aug & Fingerlings & Skin & 56 & -0.33 & 0.01 \\
& & Gills & 56 & -0.36 & $<0.01$ \\
7 Sep & Pre-smolt & Skin & 46 & -0.30 & 0.04 \\
28 Sep & Pre-smolt & Skin & 41 & 0.06 & 0.70 \\
\hline
\end{tabular}

This behaviour was also observed in fish when no Ichthyobodo infections could be detected. An area of scale loss or small ulcers, typically lateral below the dorsal fin, was common in August to September when flashing was most prominent. These lesions were common on both the left and right body sides, but were more prominent on the Ichthyobodo-infected fish
(Table 4). Statistical analysis of these observations confirmed that there was a significant positive association between skin damage and Ichthyobodo skin infection $\left(\chi^{2}{ }_{1}=68.9, \mathrm{n}=143, \mathrm{p}<0.001\right)$.

During the present study, the monthly mortality was low: $1.0 \%$ (range 0 to $2.2 \%$ ) $\mathrm{mo}^{-1}$ in April to July and $<1 \%$ when Ichthyobodo infections occurred in August to September. However, an incident of relatively high mortality $(6.6 \%)$ occurred among fry in March following a prophylactic formalin treatment.

\section{Wild fish}

Ichthyobodo infections were observed on threespined stickleback and brown trout in June 2001, with a prevalence of $74 \%(n=31)$ and $27 \%(n=15)$, respectively (Table 5). The infections in sticklebacks coincided with host-spawning, and moderate to heavy infections were recorded. Infections on brown trout were slight. Heavy and slight infections were seen on wild salmon (2 of 5) caught in October.

Table 4. Ichthyobodo necator infecting Salmo salar. Ranked intensities of infection among farmed Atlantic salmon in August (fingerlings) and September (pre-smolt). Intensities of infection are given on a scale from 0 to 3 (none to heavy infection). Salmon length $(\mathrm{mm})$, haematocrit values (Hct, \%) and condition factor (Fulton's K) are given as mean $( \pm$ SD). Hct was not measured in all fish; thus $\mathrm{N}(\mathrm{Hct}) \neq \mathrm{N}$ (total). The proportion of fish with skin lesions is given for each infection category

\begin{tabular}{|c|c|c|c|c|c|c|c|}
\hline $\begin{array}{l}\text { Sampling } \\
\text { date }\end{array}$ & $\begin{array}{l}\text { Ichthyobodo } \\
\text { infection }\end{array}$ & $\begin{array}{c}\mathrm{N} \\
\text { (total) }\end{array}$ & $\begin{array}{c}\mathrm{N} \\
\text { (Hct) }\end{array}$ & $\begin{array}{l}\text { Length } \\
(\mathrm{mm})\end{array}$ & $\begin{array}{l}\text { Hct } \\
(\%)\end{array}$ & K & $\begin{array}{c}\text { Skin } \\
\text { lesion (\%) }\end{array}$ \\
\hline \multirow[t]{4}{*}{$18 \mathrm{Aug}$} & 0 & 43 & 23 & $139(24)$ & $50.4(5.5)$ & $1.10(0.07)$ & 0 \\
\hline & 1 & 2 & 2 & $138(1)$ & $50.0(1.4)$ & $1.09(0.12)$ & 50 \\
\hline & 2 & 0 & - & - & - & - & - \\
\hline & 3 & 11 & 11 & $122(13)$ & 32.4 (19.3) & $0.98(0.10)$ & 73 \\
\hline \multirow[t]{4}{*}{$7 \mathrm{Sep}$} & 0 & 35 & 23 & $173(30)$ & $50.1(3.6)$ & $1.11(0.11)$ & 17 \\
\hline & 1 & 7 & 6 & $173(13)$ & $48.8(0.4)$ & $1.12(0.08)$ & 76 \\
\hline & 2 & 2 & 1 & $162(1)$ & 49.0 & $1.04(0.02)$ & 100 \\
\hline & 3 & 2 & 1 & $116(7)$ & 46.5 & $0.88(0.17)$ & 50 \\
\hline \multirow[t]{4}{*}{$28 \mathrm{Sep}$} & 0 & 19 & 19 & $199(26)$ & $59.7(6.5)$ & $1.10(0.08)$ & 16 \\
\hline & 1 & 11 & 10 & $190(29)$ & $59.3(12.6)$ & $1.09(0.07)$ & 73 \\
\hline & 2 & 5 & 5 & $200(24)$ & $63.2(12.7)$ & $1.17(0.07)$ & 80 \\
\hline & 3 & 6 & 6 & 209 (14) & $61.6(10.4)$ & $1.11(0.06)$ & 100 \\
\hline
\end{tabular}

Table 5. Ichthyobodo infections in wild caught freshwater fish. $\mathrm{N}=$ number of fish examined. Fish size given as length in $\mathrm{cm}$ (min.-max.). Salmon and rainbow trout do not occur naturally, and represent escaped fish from net pens in the lake

\begin{tabular}{|c|c|c|c|c|c|c|}
\hline \multirow[t]{2}{*}{ Host } & \multirow[t]{2}{*}{ Sampling period } & \multirow[t]{2}{*}{$\mathrm{N}$} & \multirow[t]{2}{*}{ Size } & \multicolumn{2}{|c|}{ Infected } & \multirow{2}{*}{$\begin{array}{l}\text { Period of } \\
\text { infection }\end{array}$} \\
\hline & & & & Gills & Skin & \\
\hline Brown trout Salmo trutta & Spring, summer, autumn & $32^{\mathrm{a}}$ & $18-35$ & $0^{\mathrm{b}}$ & 4 & June \\
\hline Atlantic salmon Salmo salar & Spring, autumn & 33 & $19-32$ & $0^{\mathrm{c}}$ & 2 & October \\
\hline Rainbow trout Oncorhynchus mykiss & Spring, summer, autumn & 16 & $21-29$ & 0 & 0 & - \\
\hline Arctic charr Salvelinus alpinus & Spring & 6 & $25-30$ & 0 & 0 & - \\
\hline Stickleback Gasterosteus aculeatus & Summer, autumn & $44^{\mathrm{d}}$ & $3-5$ & 7 & 21 & June \\
\hline
\end{tabular}




\section{Identification of Ichthyobodo species}

The specific primer sets CoNecF1 / R1 and CoEurF1 / R1 amplify 488 bp and 302 bp products from the SSU rDNA of Ichthyobodo necator s.s. and Ichthyobodo sp. II sensu Todal et al. (2004), respectively. PCR on Ichthyobodo samples from skin and gills of the hatchery-reared salmon at different periods of infection, wild brown trout and three-spined stickleback yielded product with the $\mathrm{CoNec}$ primers but not with the CoEur primers. Hence Ichthyobodo sp. II was not detected in our material. Partial SSU rDNA sequences from positive samples showed $100 \%$ identity (Ichthyobodo from salmon skin, GenBank accession no GQ184296; salmon gill, GQ184295; stickleback skin, GQ184297) with Ichthyobodo necator s.s. (Todal et al. 2004, GenBank accession no. AY224691). Two positions in the Ichthyobodo sequence from a salmon gill infection (GQ184295) were ambiguous (Y). A 1453nucleotide partial SSU rDNA sequence obtained from a lightly infected wild trout (GQ184298) also showed 99.9\% identity with I. necator s.s. (AY224691).

\section{DISCUSSION}

Previous studies on the epizootiology of Ichthyobodo spp. infections ( $I$. necator s.l.) in freshwater-reared Atlantic salmon did not apply molecular methods to identify the parasites involved (Robertson 1979, Wootten \& Smith 1980, Rintamaki-Kinnunen \& Valtonen 1997). This hampers the acquisition of epizootiological information about the actual Ichthyobodo species involved. Farmed Atlantic salmon in Norway may be infected with I. necator s.s. (Isaksen et al. 2007) and Ichthyobodo sp. II sensu Todal et al. (2004). The parasite I. necator s.s. is only known from fresh water, while Ichthyobodo sp. II is known to infect salmonids in both fresh water and full seawater. Hence Ichthyobodo sp. II is a euryhaline species. In the present study, we used specific PCR assays to confirm that all gill and skin Ichthyobodo infections from different phases of the production indeed represent $I$. necator s.s., excluding the possibility of concurrent Ichthyobodo sp. II infections. We also confirmed the claim by Todal et al. (2004) that sticklebacks are infected with the same species as the hatchery-reared salmon (i.e. I. necator s.s.), and also for the first time discovered I. necator s.s. in an adult wild-caught salmonid (brown trout).

In the hatchery, Ichthyobodo necator s.s. first transiently occurred on the skin and gills of salmon after commencement of first feeding (fry) in March and then again 20 to $30 \mathrm{wk}$ later in July to September on fingerlings and pre-smolt. There are 2 potential sources of the infection at first feeding: directly from the eggs at hatching (cf. Houghton \& Bennett 1982) or from waterborne parasites (Bauer 1959, Hlond 1963, Zitnan \& Cankovic 1970, Wootten \& Smith 1980, Valtonen \& Koskivaara 1994). Houghton \& Bennett (1982) found Ichthyobodo infections on rainbow trout eggs, and considered it likely that these were the source of subsequent infections and ichthyobodosis in the fry. However, in the present case we did not detect Ichthyobodo infections on eggs or alevins, so the likely source of infection at first feeding in our study is the inlet water. Since we found $I$. necator s.s.-infected sticklebacks and salmonids in the lakes supplying the hatchery with water, these wild fish most likely act as reservoir hosts. In addition to the obvious possibility that detached Ichthyobodo parasites survive long enough in the water to enter the hatchery and instigate infections, several authors have reported the production of cysts in Ichthyobodo spp. (as I. necator s.l.) (Bauer 1959, Robertson 1985). If confirmed, the existence of such cysts, produced for instance in autumn to winter, could be the source of infections in the heated hatchery water during first feeding.

Among the fry, the larger ones seemed to be more prone to infection on the skin, while infections on the gills were more common among the smaller fish. Robertson (1979) reported a similar pattern of infection in a Scottish rainbow trout farm. The increase and decrease of infections on skin and gills of salmonid fry and fingerlings have been reported frequently (Robertson 1979, Wootten \& Smith 1980, RintamakiKinnunen \& Valtonen 1997, Ogut \& Akyol 2007, Balta et al. 2008). The cause for this pattern in freshwater salmonid culture is unclear. It might be a result of epidermal changes in the skin and gills or development of immunity, and re-infection with the parasites (a second peak of infection) is suggested to be a result of a depressed immune response caused by environmental stressors (Robertson 1985). The first peak of infection in our study occurs subsequent to the hatching of naturally spawned salmonid fry in tributaries to the lakes supplying the hatchery water. These may therefore also be the source of Ichthyobodo necator s.s. for the spring peak. Hence this phenomenon may be part of the natural cycle of $I$. necator s.s. on salmonids, a possibility that warrants further study. The seasonal coincidence of heavily infected sticklebacks in the water source and higher water temperature in summer may also contribute to the second peak of Ichthyobodo infection observed in the present study.

The smaller fingerlings were more heavily infected than larger ones, but higher prevalence of infection was later detected among the larger pre-smolt in the net pens with relatively low rearing densities compared to the tank-reared fish (Table 1). The lower water flux in net pens compared to the fish tanks might 
increase the exposure time and reduce the loss of the parasites.

Clinical signs typically associated with ichthyobodosis, i.e. greyish coating on the body surface and 'flashing' were most frequently observed among the infected fingerlings and pre-smolt in August and September. These parasite infections were also significantly associated with scale losses and small ulcers in the skin, particularly in fingerlings and pre-smolt. Such skin lesions might be a result of physical injury caused by handling, worsened by secondary infections. The lesions were located laterally in the area below the dorsal fin, on one or both sides of the fish, i.e. the same area where Ichthyobodo necator s.s. is abundant. Still we cannot confidently ascribe the lesions to the $I$. necator s.s. infections since the irritated or damaged epithelia may have allowed the parasites to flourish in this particular area (i.e. a secondary infection; see Benisch 1936). Negative correlations were observed between intensity of infection and both haematocrit values and the condition factor, which might indicate a pathogenic effect on the host. However, both effects were associated with and may also result from the epidermal lesions. Such accompanying host debilitation may promote an opportunistic I. necator s.s. proliferation.

The use of formalin has been reported to be the most effective treatment for Ichthyobodo infections (Tojo et al. 1994, Ostland \& Byrne 1995, Balta et al. 2008). Prophylactic and therapeutic formalin treatments have been extensively used in Norwegian salmonid hatcheries to avoid ichthyobodosis. In the present study, formalin treatments seemed ineffective, since when the second peak of infection occurred (July to August), the prevalence of I. necator s.s. infection increased despite 2 formalin treatments. Both suboptimal treatment procedures (insufficient treatment time or weak dosage or both) and formalin resistance have been suggested to explain such observations (Robertson 1985, Holm 2002).

Moderate Ichthyobodo necator s.s. infections were also observed to disappear untreated, and also disappeared following vaccination against bacterial diseases. Both observations indicate development of immunity against the parasite (Robertson 1985); however, the second event may be due both to the use of tricaine as the anaesthetic and unspecific immunestimulation due to the vaccine adjuvants (Buchmann et al. 2001, Alvarez-Pellitero 2008). Notably, Callahan \& Noga (2002) found that the use of unbuffered tricaine in euthanising fish decreases the motility of Ichthyobodo sp. (I. necator s.l.) at low concentrations (50 mg $\mathrm{l}^{-1}$ ) and causes the flagellates to completely detach at higher doses $\left(1 \mathrm{~g} \mathrm{l}^{-1}\right)$. These observations point to novel avenues that may be exploited for Ichthyobodo spp. control. Optimal rearing conditions (i.e. minimum handling and crowding stress, sufficient water flux) and unspecific immune-stimulation might be effective in I. necator s.s. control without use of therapeutics. Furthermore, if I. necator s.s.-positive wild fish (salmonids and sticklebacks) are present in the water source, precautions such as water treatment (filtration and UV radiation) or deeper water inlets might be effective prophylaxis for reducing Ichthyobodo infections in salmon hatcheries. Seasonal occurrences of I. necator s.s. among wild fish need further examination to reveal natural peaks of such parasite intensities in lakes and rivers.

\section{LITERATURE CITED}

Alvarez-Pellitero P (2008) Fish immunity and parasite infections: from innate immunity to immunoprophylactic prospects. Vet Immunol Immunopathol 126:171-198

Balta F, Kayis S, Altinok I (2008) External protozoan parasites in three trout species in the Eastern Black Sea region of the Turkey: intensity, seasonality, and their treatments. Bull Eur Assoc Fish Pathol 28:157-162

Bauer ON (1959) Parasites of freshwater fish and the biological basis for their control. Bull State Sci Res Inst Lake River Fish 49:15-18

Benisch J (1936) Untersuchungen über Costia necatrix Leclerq. Z Fisch Hilfswiss 34:755-770

Buchmann K, Bresciani J (1997) Parasitic infections in pondreared rainbow trout Oncorhynchus mykiss in Denmark. Dis Aquat Org 28:125-138

Buchmann K, Lindenstrom T, Bresciani J (2001) Defence mechanisms against parasites in fish and the prospect for vaccines. Acta Parasitol 46:71-81

Callahan HA, Noga EJ (2002) Tricaine dramatically reduces the ability to diagnose protozoan ectoparasite (Ichthyobodo necator) infections. J Fish Dis 25:433-437

Callahan HA, Litaker RW, Noga EJ (2002) Molecular taxonomy of the suborder Bodonina (order Kinetoplastida), including the important fish parasite, Ichthyobodo necator. J Eukaryot Microbiol 49:119-128

Callahan HA, Litaker RW, Noga EJ (2005) Genetic relationships among members of the Ichthyobodo necator complex: implications for the management of aquaculture stocks. J Fish Dis 28:111-118

Henneguy LF (1883) Sur un infusoire flagelle, ectoparasite des poissons. C R Hebd Seances Acad Sci 96:658-660

Hlond S (1963) Occurence of Costia necatrix Henneguy on the roe of the carp. Wiad Parazytol 9:249-251

Holm JA (2002) Formalin — effektivt mot parasitter på fisk. Aquavisa 2

Houghton G, Bennett CE (1982) Costia necatrix (Henneguy, 1883), a lethal parasite of rainbow trout, Salmo gairdneri (Richardson). Proc Brit Soc Parasitol 48:217-426

Isaksen TE, Karlsbakk E, Nylund A (2007) Ichthyobodo hippoglossi n. sp. (Kinetoplastea: Prokinetoplastida: Ichthyobodonidae fam. nov.), an ectoparasitic flagellate infecting farmed Atlantic halibut Hippoglossus hippoglossus. Dis Aquat Org 73:207-217

Ogut H, Akyol A (2007) Prevalence and intensity of ectoparasites in rainbow trout (Oncorhynchus mykiss) from larvae stage to market size in Turkey. Isr J Aquacult Bamidgeh 59:23-31 
Ostland VE, Byrne PJ (1995) Comparison of formalin and chloramin-T for control of a mixed gill infection (bacterial gill disease and ichthyobodiasis) in rainbow trout. J Aquat Anim Health 7:118-123

Rintamaki-Kinnunen P, Valtonen ET (1997) Epizootiology of protozoans in farmed salmonids at northern latitudes. Int $\mathrm{J}$ Parasitol 27:89-99

Robertson DA (1979) Host-parasite interactions between Ichtyobodo necator (Henneguy, 1883) and farmed salmonids. J Fish Dis 2:481-491

Robertson DA (1985) A review of Ichthyobodo necator (Henneguy, 1883) an important and damaging fish parasite. In: Muir JF, Roberts RJ (eds) Recent advances in aquaculture. Croom Helm, London, p 1-30

Siegel S, Castellan N (1988) Measures of association and their tests of significance. In: Anker JD (ed) Nonparametric statistics for the behavioural sciences, 2nd edn. McGraw-Hill, New York, p 254-262

Editorial responsibility: Dieter Steinhagen, Hannover, Germany
Todal JA, Karlsbakk E, Isaksen TE, Plarre H and others (2004) Ichthyobodo necator (Kinetoplastida) - a complex of sibling species. Dis Aquat Org 58:9-16

> Tojo JL, Santamarina MT, Leiro J, Ubeira FM, Sanmartin ML (1994) Pharmacological treatments against Ichthyobodo necator (Henneguy, 1883) in rainbow trout, Oncorhynchus mykiss (Walbaum). J Fish Dis 17:135-143

Valtonen ET, Koskivaara M (1994) Relationships between the parasites of some wild and cultured fishes in two lakes and a fish farm in central Finland. Int $\mathrm{J}$ Parasitol 24:109-118

Wootten R, Smith JW (1980) Studies on the parasite fauna of juvenile Atlantic salmon, Salmo salar L., cultured in fresh water in eastern Scotland. Z Parasitenkd 63:221-231

Zitnan R, Cankovic M (1970) Comparison of the epizootological importance of the parasites of Salmo gairdneri irideus in the two coast areas of Bosna and Herzegovina. Helminthologia 11:161-165

Submitted: May 25, 2009; Accepted: November 2, 2009 Proofs received from author(s): February 4, 2010 